\title{
CALCULATION OF SUSTAINABLE DEVELOPMENT INDEX IN THE EU AND UKRAINE
}

\author{
Olena Khanova \\ Karazin Kharkiv National University \\ sq. Svobody 6, 61022 Kharkiv, Ukraine, e.v.khanova@karazin.ua \\ https://orcid.org/0000-0002-0681-4860 \\ Igor Matyushenko \\ Karazin Kharkiv National University \\ sq. Svobody 6, 61022 Kharkiv, Ukraine, imatyushenko@karazin.ua \\ (D) https://orcid.org/0000-0001-9866-9025 \\ Ewa Kochańska \\ Research and Innovation Centre Pro-Akademia, \\ Innowacyjna 9/11, 95-050 Konstantynow Lodzki, Poland, ewa.kochanska@proakademia.eu \\ (D) https://orcid.org/0000-0002-4735-796 \\ Viktoriia Tretyak \\ Karazin Kharkiv National University \\ sq. Svobody 6, 61022 Kharkiv, Ukraine, v.tretiak@karazin.ua \\ https://orcid.org/0000-0002-5225-8754 \\ Olga Tofaniuk \\ National Aerospace University "KhAl" \\ st. Chkalova, 17, 61070 Kharkiv, Ukraine, cooperationkhai@gmail.com \\ https://orcid.org/0000-0002-2758-6705
}

Article history: Received 7 July 2021, Received in revised form 23 August 2021, Accepted 23 August 2021, Available online 23 August 2021

\begin{abstract}
It is proposed using certain indicators to assess the sustainable development of the EU countries and Ukraine: for the economic measuring - the global competitiveness index, the global innovation index and the index of economic freedom; for the social measuring - the social progress index, the human development index, quality of life index; for the environmental measuring - environmental performance index. The analysis of each selected indices of the EU countries and Ukraine is carried out. The methodology for calculating the ratio of the economic, social and environmental components of sustainable development for each EU country and Ukraine is presented. Attention is focused on the significant regional diversification of sustainable development and its components in the EU countries and Ukraine; the highest, middle and lowest levels of sustainable development of counties are identified.

Impact: the methodology for the study of sustainable development, proposed by the authors on the example of the EU countries and Ukraine, is based on objective international ratings that have a transparent calculation methodology. These international ratings are constantly updated and cover most of the countries of the world. Therefore, the proposed methodology makes it possible to identify countries with the highest level of economic, social and environmental development; calculate the index of sustainable development of any country in the world.
\end{abstract}

\section{Keywords}

sustainable development Index, European Union and Ukraine, calculation methodology, sustainable development indicators

\section{Introduction}

In modern conditions, more and more doubts are being placed on the expediency of development, in the centre of which is the material production. This necessitates a change in the entire paradigm - from the ideology of accumulating material wealth on earth to the ideology of "reasonable sufficiency", from the ideology of competition 
to the mutual assistance one. Approaches to sustainable development are constantly being improved in the countries of the European Union, therefore, it is expedient to study methodologies and indicators for assessing sustainable development, which determines the relevance of the study.

The scientific works of many researchers are devoted to the study of sustainable development processes. In particular, in the works of G. H. Brundtland [1], the use of the term "sustainable development" and the concept of sustainable development of the world was first proposed. A number of scientists at the end of the twentieth century investigated the compliance of the modern economy with the rules of a stable state [2], the need to implement a global policy on sustainable consumption and production [3], global problems associated with modeling the growth of the planet's population and the simultaneous depletion of natural resources [4], historical background ideas of sustainable development [5], the prospects of modeling scientific policy to provide global information to human society, finding out the possibilities for coordinating policies between countries in order to achieve sustainable development of the world economy in the context of the constraints of the global environment [6].

Modern works are devoted to interaction of many aspects of the social, economic and environmental component and sustainable development of society. Some of them disclose methods of air transport safety integration in the mechanism of interaction between sustainable development goals and sustainable development safety management through managerial, functional and informational links between sustainable development subsystems and various hierarchical safety levels [7]. The work of N. Dalevska, V. Khobta, A. Kwilinski, S. Kravchenko [8] proposes a methodology and tools of economic and mathematical modeling to assess the level of international trade development and investment relations, the life expectancy, the standard of living and prosperity of international entities under the influence of sources of economic growth in the context of sustainable development. Researchers of Sumy State University Ukraine consider the impact of macroeconomic stability on improving the energy efficiency of countries [9], and assesses the growth of competitiveness in the world market during the reorientation from a traditional to a sustainable business model [10]. Sustainable business models draw attention to a long-term business perspective, which takes into account both evolutionary changes in the economic, technological, environmental and social dimensions, but also changes that occur suddenly and radically impact the economic eco-systems.

The ecological aspects of sustainable development are considered in work [11]. It is said that the formation and use of waste is one of the main problems of civilization, and the implementation of sustainable development concept goals is one of the solutions to this issue. In work [12] attention is focused on assessing the impact of climate change and environmental sustainability of the modern world.

The work [13] is devoted to the analysis of the structure and dynamics of scientific publications in the field of environmental management and social marketing in their interconnection. The proceeding [14] focuses on the search for systemic solutions to multidisciplinary problems of the international economy and globalization in the context of innovative development, information technology and sustainable development.

The work [15] views the patterns of development of open stationary systems on the example of processes and phenomena in nature and society, as well as the interconnection between the energy and information characteristics of transformation processes. It also analyzes the concept of "sustainable development of socio-economic systems", basic principles, methods and tools for ensuring sustainable development of social systems. Researchers [16,17] attempted to assess the sustainable development of the country using the index method.

Works of $2020[18,19]$ are related to the sustainable development of the global health system and its transformation to stable state, given the COVID-19 pandemic.

At the same time, the transition to an information society leads to a change in the structure of total capital in favour of human capital, increasing the intangible flows of finance, information and intellectual property. These flows have already exceed the volume of movement of tangible goods by seven times [20]. The development of a new, "weightless" economy is stimulated not only by a shortage of natural resources and care of the natural environment, but also by an increase in the volume of information and knowledge, acquiring the value of a demanded product.

From the environmental point of view, sustainable development should ensure the integrity of biological and physical natural systems, their viability. The global stability of the entire biosphere depends on this. As a result of insufficient monitoring of the impact of climate change and postponed preventive actions, are environmental disasters, which affect the economic development and living conditions for people. This situation is observed especially in the countries of the global south, e.g. in Brazil [21].

The ability to assess the environmental, economic and social threats properly is of particular importance. The tools like a novel approach to the Sustainable Development Index calculation can help to measure the progress of realization of sustainable development goals in many different areas of industrial activity. SDI as well as the Life Cycle Assessment tools should be continuously developed [22,23]. 


\section{Methods}

Theory and practice have shown that at the turn of the century V. Vernadsky's teaching about the noosphere turned out to be a necessary platform for developing a triune concept of sustainable ecological, socio-economic development. The generalization of this concept was made by the United Nations world summits in 1992 and 2002, with the participation of more than 180 countries of the world, many international organizations and leading scientists. Thus, the new concept systematically combined the three main components of sustainable development of society: economic, environmental and social.

The economic approach consists in the optimal use of limited resources and the use of nature-, energy- and materialsaving technologies to create a flow of aggregate income, which would ensure at least the conservation (not decrease) of the aggregate capital (physical natural or human), with the use of which this aggregate income is created. The social component is focused on the development of society, on maintaining the stability of social and cultural systems, on reducing the number of conflicts in society. From the ecology point of view, sustainable development should ensure the integrity of biological and physical natural systems, their viability. The global stability of the entire biosphere depends on this. The ability of such systems to self-renew and adapt to various changes is of particular importance, instead of being preserved in a certain static state or degradation and loss of biological diversity.

Systematically harmonization and balancing of these three components is a challenge, especially in time of the global economy transition caused by COVID-19. In particular, the interconnection of social and environmental components leads to necessity of preserving the same rights of use natural resources by today's and future generations. The interaction of social and economic components requires the achievement of justice in the distribution of material wealth between people and the provision of targeted assistance to the relevant strata of society. And, finally, the interaction between the environmental and economic components requires an assessment of the man-made impacts cost on the environment. Solving these problems is the main our time challenge for national governments, authoritative international organizations, etc.

According to the proposed methodology, the economic component is the resulting index of the country's score according to The Global Competitiveness Index, Global Innovation Index and Index of Economic Freedom. Social component is the resulting index of the country's score according to The Social Progress Index, Human Development Index and Quality of life index. Environmental component is the resulting index of the country score according to the Environmental Performance Index. If the study requires, these components can be replaced with another ones.

Calculation algorithm:

1. the average indicator calculation for each of the ratings;

2. the score standardization of each country in the rating by dividing the rating score by the average for the rating;

3. calculation of the economic component from standardised indicators for each country according to the methodology for calculating the integral human development index:

$$
\text { Economic component }=\sqrt[3]{\mathrm{GCI} \times \mathrm{GII} \times \mathrm{IEF}}
$$

where $\mathrm{GCl}$ - is a standardised indicator according to The Global Competitiveness Index, GII - is a standardised indicator according to the Global Innovation Index, IEF - is a standardised indicator according to the Index of Economic Freedom.

4. calculation of the social component from standardised indicators for each country according to the methodology for calculating the integral human development index:

$$
\text { Social component }=\sqrt[3]{\mathrm{SPI} \times \mathrm{HDI} \times \mathrm{QLI}}
$$

where SPI - is a standardised indicator for The Social Progress Index, HDI is the standardised indicator for the Human.

Development Index, QLI is the standardised indicator for the Quality of Life Index.

5. the environmental component standardization by dividing the rating score by the rating average;

6. the index of sustainable development calculation of the world countries with using of index method and method for calculating the integral index of human development, adapted to the indicators of sustainable development is proposed, namely:

$S D I=$

\footnotetext{
$\sqrt[3]{\text { Economic component } \times \text { Social component } \times \text { Environmental component }}$
}

where SDI - Sustainable Development Index. 


\section{Results and discussion}

Sustainable development is a system of mutually agreed management, economic, social, environmental protection measures aimed at forming a system of public relations based on the principles of trust, partnership, solidarity, consensus, ethical values, a safe environment, and national sources of spirituality. Among the main components that ensure sustainable development are the following:

- economic - involves the formation of an economic system harmonised with ecological and social factors of development;

- $\quad$ social - confirms the human rights to a high standard of living in conditions of environmental safety and wellbeing, that has become one of the important signs of social protection;

- environmental - defines the conditions and boundaries of the restoration of ecological systems as a result of their operation.

The formation of indicators system for quantitative and qualitative assessment of this multidimensional process is an important problem on the way of implementing of sustainable development concept.

The article proposes the novel approach to the Sustainable Development Index calculation. The multidimensional sustainable development index and for the countries of the European Union and Ukraine according to above described methodology.

1. The economic measuring of sustainable development is determined on the basis of three global indicators:

The first is the Global Competitiveness Index, developed by the organisers of the World Economic Forum and published in the form of the so-called "Global Competitiveness Report". The competitiveness index is formed from three following components: the indicator of the macroeconomic environment (basic requirements), the indicator of the country's technological development (innovation factors) and the indicator of "factors that enhance production" (efficiency enhancers). In turn, these three indicators are calculated basing on the use of 9 data sets of macroeconomic indicators, the level of infrastructure development, the health status of the population and its level of education, the technological readiness of the economy, the level of market efficiency, etc.

The EU countries and Ukraine have different levels of competitiveness [24], that is shown in Table 1.

Table 1. Global Competitiveness Index of EU countries and Ukraine. Source: the study based on GCI WEF 2019

\begin{tabular}{|c|l|c|c|l|c|}
\hline No. & \multicolumn{1}{|c|}{ Economy } & GCI WEF & No. & Economy & GCI WEF \\
\hline 1 & Austria & 76.609131 & 15 & Ireland & 75.116213 \\
\hline 2 & Belgium & 76.380122 & 16 & Italy & 71.528281 \\
\hline 3 & Bulgaria & 64.895011 & 17 & Lithuania & 68.351613 \\
\hline 4 & Cyprus & 66.385446 & 18 & Luxembourg & 77.028126 \\
\hline 5 & Czech Republic & 70.852799 & 19 & Latvia & 66.980444 \\
\hline 6 & Germany & 81.796537 & 20 & Malta & 68.546119 \\
\hline 7 & Greece & 62.58073 & 21 & Netherlands & 82.39217 \\
\hline 8 & Denmark & 81.174898 & 22 & Poland & 68.893312 \\
\hline 9 & Spain & 75.279405 & 23 & Portugal & 70.44752 \\
\hline 10 & Estonia & 70.90714 & 24 & Romania & 64.355621 \\
\hline 11 & Finland & 80.24563 & 25 & Slovak Republic & 66.772277 \\
\hline 12 & France & 78.80624 & 26 & Slovenia & 70.200786 \\
\hline 13 & Croatia & 61.938131 & 27 & Sweden & 81.247188 \\
\hline 14 & Hungary & 65.075071 & 28 & Ukraine & 56.992175 \\
\hline
\end{tabular}

As it can be seen, all EU countries, despite a certain diversity, are included in the first half of the ranking (Greece and Croatia have the worst competitiveness).

Although the leading European countries are constantly increasing their competitiveness in almost all areas, there is also a wide differentiation in terms of the components of competitiveness. The average EU indexes are the lowest in terms of innovation performance. The countries are clearly divided, with a significant gap between the innovation scores for Northern and Western Europe compared to Central, Eastern and Southern Europe. Accelerating the development of the innovative component is crucial for maintaining the current level of well-being, and EU countries can expect a high return of investment in this particular component.

The second is the Global Innovation Index, compiled by the World Intellectual Property Organization, Cornell University 
and "Insead» International Business School. The research has been conducted since 2007. The research is under government control and is aimed at studying economic processes and is annually carried out. The Global Innovation Index is composed by 82 different variables that characterise the innovative development of countries around the world at different levels of economic development in detail.

The EU countries and Ukraine have different levels of innovative development [25], that is shown in Table 2.

Table 2. Global Innovation Index of the EU and Ukraine. Source: the study based on GII 2019

\begin{tabular}{|c|l|c|c|l|c|}
\hline No. & \multicolumn{1}{|c|}{ Economy } & GII & No. & Economy & GII \\
\hline 1 & Austria & 50.94 & 15 & Ireland & 56.10 \\
\hline 2 & Belgium & 50.18 & 16 & Italy & 46.30 \\
\hline 3 & Bulgaria & 40.35 & 17 & Lithuania & 41.46 \\
\hline 4 & Cyprus & 48.34 & 18 & Luxembourg & 53.47 \\
\hline 5 & Czech Republic & 49.43 & 19 & Latvia & 43.23 \\
\hline 6 & Germany & 58.19 & 20 & Malta & 49.01 \\
\hline 7 & Greece & 38.90 & 21 & Netherlands & 61.44 \\
\hline 8 & Denmark & 58.44 & 22 & Poland & 41.31 \\
\hline 9 & Spain & 47.85 & 23 & Portugal & 44.65 \\
\hline 10 & Estonia & 49.97 & 24 & Romania & 36.76 \\
\hline 11 & Finland & 59.83 & 25 & Slovak Republic & 42.05 \\
\hline 12 & France & 54.25 & 26 & Slovenia & 45.25 \\
\hline 13 & Croatia & 37.82 & 27 & Sweden & 63.65 \\
\hline 14 & Hungary & 44.51 & 28 & Ukraine & 37.40 \\
\hline
\end{tabular}

Table 2. shows, that the EU countries have significant differences in the innovative component development of their economies. The Netherlands, Sweden, Finland have the highest innovative development, the lowest - Greece, Croatia, Romania).

The third is the Index of Economic Freedom (IEF), created by the intellectual center "Heritage Foundation". The IEF consists of 12 indicators (economic freedoms): 1) freedom of business activity (Business Freedom) 2) transparency of the country's trade policy (Trade Freedom) 3) fiscal policy of the government (Fiscal Freedom) 4) government regulatory policy (Freedom from Government) 5) monetary policy (Monetary Freedom) 6) attracting capital and foreign investment (Investment Freedom) 7) freedom of banking and financial activities (Financial Freedom) 8) observance of private property rights (Property Rights) 9) ensuring labor rights and freedoms (Labor Freedom) 10) efficiency of judicial activity (Judicial Effectiveness) 11) tax burden (Tax Burden) 12) government spending (Gov't Spending).

These twelve indicators are defined from 50 diverse sets of economic, financial, legislative and administrative data.

Economic freedom is the fundamental right of every person to manage their own labor and property. In economically free societies, individuals are free to choose jobs, goods production, spendings and investments in any way they want. All these freedoms are supported and protected by the state. In economically free societies, government also allows free moving of labor, capital, and goods. Government refrains from coercion and pressure on freedoms, intervenes only if it is necessary to preserve and function itself.

Table 3 shows the EU countries and Ukraine Index of Economic Freedom [26].

The weight of each of the 112 factors is considered in the same way, so the general index is the arithmetic mean of the indicators. All countries according to this index are divided into the following groups:

- free, with an indicator of 80-100 (Ireland);

- mostly free, with an indicator of 70-79.9 (these countries are: Austria, Belgium, Bulgaria, Cyprus, Czech Republic, Germany, Denmark, Estonia, Finland, Lithuania, Luxembourg, Latvia, Malta, Netherlands, Sweden);

- moderately free, with an indicator of 60-69.9 (these countries are: Greece, Spain, France, Croatia, Hungary, Italy, Poland, Portugal, Romania, Slovakia, Slovenia);

- mostly not free, with an indicator of 50-59.9 (this group includes Ukraine);

- despotic, with an indicator of 0-49.9 (none of the studied countries belongs to this group). 
Table 3. Index of Economic Freedom of the EU countries and Ukraine. Source: the study based on IEF 2021

\begin{tabular}{|c|l|c|c|l|c|}
\hline No. & \multicolumn{1}{|c|}{ Economy } & IEF & No. & \multicolumn{1}{|c|}{ Economy } & IEF \\
\hline 1 & Austria & 73.9 & 15 & Ireland & 81.4 \\
\hline 2 & Belgium & 70.1 & 16 & Italy & 64.9 \\
\hline 3 & Bulgaria & 70.4 & 17 & Lithuania & 76.9 \\
\hline 4 & Cyprus & 71.4 & 18 & Luxembourg & 76.0 \\
\hline 5 & Czech Republic & 73.8 & 19 & Latvia & 72.3 \\
\hline 6 & Germany & 72.5 & 20 & Malta & 70.2 \\
\hline 7 & Greece & 60.9 & 21 & Netherlands & 76.8 \\
\hline 8 & Denmark & 77.8 & 22 & Poland & 69.7 \\
\hline 9 & Spain & 69.9 & 23 & Portugal & 67.5 \\
\hline 10 & Estonia & 78.2 & 24 & Romania & 69.5 \\
\hline 11 & Finland & 66.1 & 25 & Slovak Republic & 68.3 \\
\hline 12 & France & 63.6 & 26 & Slovenia & 68.3 \\
\hline 13 & Croatia & 67.2 & 28 & Skraine & 74.7 \\
\hline 14 & Hungary & & 56.2 \\
\hline
\end{tabular}

2. The social measuring of sustainable development can be formed on the basis of three indicators:

$$
\begin{array}{ll}
-\quad \text { the Social Progress Index; } \\
\text { - } \quad \text { the Human Development Index; } \\
\text { - } \quad \text { the Quality of Life Index. }
\end{array}
$$

The Social Progress Index is a combined indicator of the international research project The Social Progress Imperative. It measures the achievements of countries around the world in terms of social welfare and social progress. It was developed in 2013 under the leadership of Michael E. Porter, Head of The Social Progress Imperative, Harvard University professor of strategic management and international competitiveness. The Index's editorial board includes representatives from a number of leading universities and research centres, including Harvard Business School and Massachusetts Institute of Technology.

The index does not include economic development indicators of the world countries (such as the level of GDP and GNI), but is intended to assess public welfare in a particular country. Since the study measures social achievement apart from economic indicators, it allows a deeper study of the interconnection between economic and social development.

More than 50 indicators are taken into account in determining the performance of a countries in the field of social progress and combined into three main groups:

- basic human needs - food, access to basic medical care, housing, access to water, electricity and sanitation, the level of personal safety;

- $\quad$ the basics of human well-being - access to basic knowledge and the level of literacy of the population, access to information and means of communication, the level of health care (especially in the context of COVID-19), environmental sustainability;

- human development opportunities - the level of personal and civil freedoms, ensuring human rights and opportunities to make decisions and realise their potential.

The index measures the performance of each country on a scale from 0 (the lowest degree of stability) to 100 (the highest degree of stability) based on the obtained data in three mentioned basic categories. Table 4 shows the data of the Social Progress Index [27] for the studied countries.

As it can be seen from Table 4, countries such as Sweden, the Netherlands, Ireland, Finland, Denmark, Germany have the highest social progress; the lowest - Bulgaria, Romania, Ukraine.

The Human Development Index (HDI) [28] consists of three indicators: population average life expectancy; level of education; country's living standard, which is measured in GDP and PPP, Table 5.

All EU countries (Table 5) according to the HDI belong to countries with a very high level of human development. Ukraine belongs to the group of countries with a high level of human development. 
Table 4. Social Progress Index of the EU countries and Ukraine. Source: the study based on SPI 2020

\begin{tabular}{|c|l|c|c|l|c|}
\hline No. & \multicolumn{1}{|c|}{ Economy } & IEF & No. & \multicolumn{1}{|c|}{ Economy } & IEF \\
\hline 1 & Austria & 89.50 & 15 & Ireland & 90.35 \\
\hline 2 & Belgium & 89.46 & 16 & Italy & 87.36 \\
\hline 3 & Bulgaria & 79.86 & 17 & Lithuania & 83.97 \\
\hline 4 & Cyprus & 86.64 & 18 & Luxembourg & 89.56 \\
\hline 5 & Czech Republic & 86.69 & 19 & Latvia & 83.19 \\
\hline 6 & Germany & 90.56 & 20 & Malta & 84.89 \\
\hline 7 & Greece & 85.78 & 21 & Netherlands & 91.06 \\
\hline 8 & Denmark & 92.31 & 22 & Poland & 84.32 \\
\hline 9 & Spain & 88.71 & 23 & Portugal & 87.79 \\
\hline 10 & Estonia & 87.26 & 24 & Romania & 78.35 \\
\hline 11 & Finland & 81.89 & 25 & Slovak Republic & 83.15 \\
\hline 12 & France & 81.92 & 27 & Sweden & 87.71 \\
\hline 13 & Croatia & 81.02 & 28 & Ukraine & 91.62 \\
\hline 14 & Hungary & & 73.38 \\
\hline
\end{tabular}

Table 5. Human Development Index of the EU and Ukraine. Source: the study based on HDI 2020

\begin{tabular}{|c|l|c|c|l|c|}
\hline No. & \multicolumn{1}{|c|}{ Economy } & HDI & No. & Economy & HDI \\
\hline 1 & Austria & 0.922 & 15 & Ireland & 0.955 \\
\hline 2 & Belgium & 0.931 & 16 & Italy & 0.892 \\
\hline 3 & Bulgaria & 0.816 & 17 & Lithuania & 0.882 \\
\hline 4 & Cyprus & 0.887 & 18 & Luxembourg & 0.916 \\
\hline 5 & Czech Republic & 0.900 & 19 & Latvia & 0.866 \\
\hline 6 & Germany & 0.947 & 20 & Malta & 0.895 \\
\hline 7 & Greece & 0.888 & 21 & Netherlands & 0.944 \\
\hline 8 & Denmark & 0.940 & 22 & Poland & 0.880 \\
\hline 9 & Spain & 0.904 & 23 & Portugal & 0.864 \\
\hline 10 & Estonia & 0.892 & 24 & Romania & 0.828 \\
\hline 11 & Finland & 0.938 & 25 & Slovak Republic & 0.860 \\
\hline 12 & France & 0.901 & 26 & Slovenia & 0.917 \\
\hline 13 & Croatia & 0.851 & 27 & Sweden & 0.945 \\
\hline 14 & Hungary & 0.854 & 28 & Ukraine & 0.779 \\
\hline
\end{tabular}

The Quality of Life Index (QLI), which is calculated by the international organization "Economist Intelligence Unit". The study uses 9 quality of life factors to determine a country's score: health - life expectancy (in years); family life divorce rate (per 1000 people), the score is from 1 (few divorces) to 5 (many divorces); public life - variable takes on the value 1 if the country has a high level of church attendance or union membership; material well-being - GDP per capita, purchasing power parity; political stability and security - ratings of political stability and security; climate and geography - latitude, to distinguish between cold and hot climates; job security - unemployment rate (in\%); political freedom average index of political and civil freedom (scale from 1 (completely free) to 7 (not free); gender equality - measured by dividing the average salary of men by the salary of women.

The EU countries and Ukraine distribution according to the Quality of Life Index [29] is given in Table 6.

As can be seen from the table, Austria, Finland, the Netherlands, Luxembourg have the highest level of quality and safety of life; the lowest have Ukraine, Romania, Bulgaria, Greece. 
Table 6. Quality of Life Index of the EU countries and Ukraine. Source: the study based on QLI 2021

\begin{tabular}{|c|l|c|c|l|c|}
\hline No. & \multicolumn{1}{|c|}{ Economy } & QLI & No. & Economy & QLI \\
\hline 1 & Austria & 182.37 & 15 & Ireland & 150.89 \\
\hline 2 & Belgium & 150.89 & 16 & Italy & 138.63 \\
\hline 3 & Bulgaria & 126.34 & 17 & Lithuania & 160.02 \\
\hline 4 & Cyprus & 144.06 & 18 & Luxembourg & 183.31 \\
\hline 5 & Czech Republic & 156.33 & 19 & Latvia & 147.59 \\
\hline 6 & Germany & 176.76 & 20 & Malta & 144.06 \\
\hline 7 & Greece & 129.86 & 21 & Netherlands & 183.31 \\
\hline 8 & Denmark & 190.01 & 22 & Poland & 132.65 \\
\hline 9 & Spain & 164.48 & 23 & Portugal & 161.91 \\
\hline 10 & Estonia & 173.56 & 24 & Romania & 131.71 \\
\hline 11 & Finland & 182.79 & 25 & Slovak Republic & 149.68 \\
\hline 12 & France & 150.73 & 26 & Slovenia & 168.20 \\
\hline 13 & Croatia & 156.10 & 27 & Sweden & 171.40 \\
\hline 14 & Hungary & 134.01 & 28 & Ukraine & 107.35 \\
\hline
\end{tabular}

3. The ecological measuring of sustainable development can be viewed using the Environmental Performance Index (EPI).

The EPI index consists of 16 indicators that show the achievements of a country on its path to sustainable environmental development. These indicators include: the level of infant mortality (deaths per 1000 children 1-14 years old), chemical pollution and dustiness $\left(\mu \mathrm{g} / \mathrm{m}^{3}\right)$ of the atmosphere, the provision of drinking water and its sufficient purification (\%), the state of ozone, the content of nitrates in drinking water ( $\mathrm{mg} / \mathrm{l}$ ), water consumption, share of natural and protected areas, degree of deforestation (\%), level of agriculture support, depletion of fish stocks, share of alternative energy sources, energy efficiency and $\mathrm{CO}_{2}$ emissions. All these evaluation criteria are presented in Table 7.

Table 7. Components of the Environmental Performance Index (EPI). Source: the study based on EPI

\begin{tabular}{|c|c|c|c|}
\hline Group & \multicolumn{3}{|c|}{ Environmental Health } \\
\hline $\begin{array}{l}\text { Political } \\
\text { categories }\end{array}$ & Effects on human health & Air pollution affecting health & Water and sanitation \\
\hline \multirow{3}{*}{ Indicators } & \multirow[t]{3}{*}{ 1. Infant mortality } & $\begin{array}{l}\text { 2. The average number of } \\
\text { particulate matter (PM 2.5) }\end{array}$ & 5. Access to sanitation \\
\hline & & $\begin{array}{l}\text { 3. The percentage of the } \\
\text { population exposed to } \\
\text { elevated PM } 2.5\end{array}$ & \multirow[t]{2}{*}{ 6. Access to drinking water } \\
\hline & & 4. Indoor air pollution & \\
\hline Group & \multicolumn{3}{|c|}{ Ecosystem vitality } \\
\hline $\begin{array}{c}\text { Political } \\
\text { categories }\end{array}$ & Climate change and energy & $\begin{array}{c}\text { Water resources (effect on the } \\
\text { ecosystem) }\end{array}$ & Biodiversity \\
\hline \multirow{4}{*}{ Indicators } & 7. The trend of carbon intensity & \multirow[t]{4}{*}{ 10. Wastewater treatment } & 11. Environmental protection \\
\hline & $\begin{array}{l}\text { 8. Changing the trend of carbon } \\
\text { intensity }\end{array}$ & & $\begin{array}{l}\text { 12. Protection of the national } \\
\text { biome }\end{array}$ \\
\hline & \multirow{2}{*}{$\begin{array}{l}\text { 9. The trend of the ratio of } \\
\text { carbon dioxide emissions to } \\
\text { kWh }\end{array}$} & & $\begin{array}{l}\text { 13. Protection of the } \\
\text { international biome }\end{array}$ \\
\hline & & & 14. Marine protected areas \\
\hline $\begin{array}{l}\text { Political } \\
\text { categories }\end{array}$ & Agriculture & Forest & Fishing \\
\hline \multirow[b]{2}{*}{ Indicators } & 15. Agricultural subsidies & \multirow{2}{*}{$\begin{array}{l}\text { 17. Changing of the forests } \\
\text { area }\end{array}$} & 18. Fishing on the coastal shelf \\
\hline & $\begin{array}{l}\text { 16. Legislation governing the } \\
\text { use of pesticides }\end{array}$ & & $\begin{array}{l}\text { 19. Exploitation of fish } \\
\text { resources }\end{array}$ \\
\hline
\end{tabular}

Country receives points for each indicator. The number of points depends on the position of the state within the range, the worst for this indicator (relative zero on a 100-point scale) and the desired goal (equivalent to one hundred points). 
All components are combined and calculated into a general index for each country, Table 8 [30].

Table 8. Environmental Performance Index of the EU countries and Ukraine. Source: the study based on EPI 2020

\begin{tabular}{|c|l|c|c|l|c|}
\hline No. & \multicolumn{1}{|c|}{ Economy } & EPI & No. & Economy & EPI \\
\hline 1 & Austria & 79.6 & 15 & Ireland & 72.8 \\
\hline 2 & Belgium & 73.3 & 16 & Italy & 71.0 \\
\hline 3 & Bulgaria & 57.0 & 17 & Lithuania & 62.9 \\
\hline 4 & Cyprus & 64.8 & 18 & Luxembourg & 82.3 \\
\hline 5 & Czech Republic & 71.0 & 19 & Latvia & 61.6 \\
\hline 6 & Germany & 77.2 & 20 & Malta & 70.7 \\
\hline 7 & Greece & 69.1 & 21 & Netherlands & 75.3 \\
\hline 8 & Denmark & 82.5 & 22 & Poland & 60.9 \\
\hline 9 & Spain & 74.3 & 23 & Portugal & 67.0 \\
\hline 10 & Estonia & 65.3 & 24 & Romania & 64.7 \\
\hline 11 & Finland & 78.9 & 25 & Slovak Republic & 68.3 \\
\hline 12 & France & 60.0 & 26 & Slovenia & 72.0 \\
\hline 13 & Croatia & 63.1 & 27 & Sweden & 78.7 \\
\hline 14 & Hungary & 28 & Ukraine & 49.5 \\
\hline
\end{tabular}

As Table 8 shows, Luxembourg, Denmark, France pursues the most effective environmental policy according to the study; the worst - Bulgaria and Ukraine.

Economic component of sustainable development is the resulting score of a country according to The Global Competitiveness Index, Global Innovation Index and Index of Economic Freedom, Table 9 and Fig. 1. This is the third stage of the calculation algorithm. Previously, the average values of the indicator for each of the ratings were found and the score of each country in the rating was standardised by dividing the rating score by the average value.

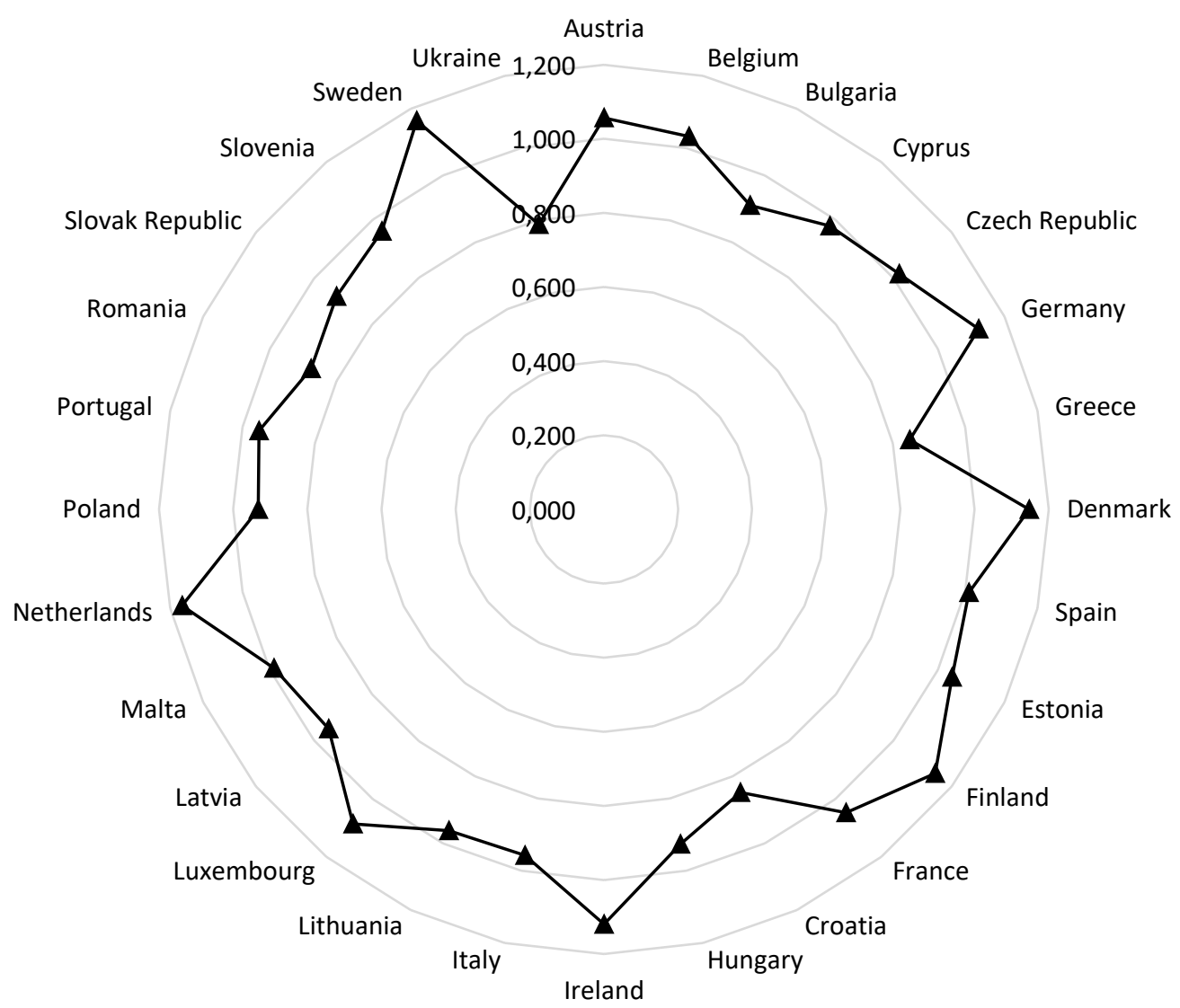

Fig.1. Economic component of sustainable development of the EU countries and Ukraine. Source: own calculations based on GCI WEF 2019; GII 2019; IEF 2021 
Table 9. Economic component of sustainable development of the EU countries and Ukraine. Source: own calculations based on GCI WEF 2019; GII 2019; IEF 2021

\begin{tabular}{|l|l|l|l|c|}
\hline Country & \multicolumn{1}{|c|}{ GCl } & \multicolumn{1}{|c|}{ GII } & \multicolumn{1}{|c|}{ IEF } & $\begin{array}{l}\text { Economic component of } \\
\text { sustainable development }\end{array}$ \\
\hline Austria & 1.071575 & 1.055689 & 1.042838 & 1.057 \\
\hline Belgium & 1.068372 & 1.039938 & 0.989215 & 1.032 \\
\hline Bulgaria & 0.907723 & 0.83622 & 0.993448 & 0.910 \\
\hline Cyprus & 0.928571 & 1.001806 & 1.00756 & 0.979 \\
\hline Czech Republic & 0.991058 & 1.024395 & 1.041427 & 1.019 \\
\hline Germany & 1.144134 & 1.205939 & 1.023082 & 1.122 \\
\hline Greece & 0.875352 & 0.80617 & 0.859389 & 0.846 \\
\hline Denmark & 1.135439 & 1.21112 & 1.097873 & 1.147 \\
\hline Spain & 1.052976 & 0.991651 & 0.986393 & 1.010 \\
\hline Estonia & 0.991818 & 1.035586 & 1.103518 & 1.043 \\
\hline Finland & 1.122441 & 1.239927 & 1.073884 & 1.143 \\
\hline France & 1.102307 & 1.124286 & 0.927124 & 1.047 \\
\hline Croatia & 0.866364 & 0.783788 & 0.89749 & 0.848 \\
\hline Hungary & 0.910242 & 0.922432 & 0.948292 & 0.927 \\
\hline Ireland & 1.050693 & 1.162625 & 1.148675 & 1.120 \\
\hline Italy & 1.000506 & 0.959529 & 0.915835 & 0.958 \\
\hline Lithuania & 0.956073 & 0.859224 & 1.085173 & 0.962 \\
\hline Luxembourg & 1.077436 & 1.108121 & 1.072473 & 1.086 \\
\hline Latvia & 0.936893 & 0.895905 & 1.02026 & 0.950 \\
\hline Malta & 0.958793 & 1.015691 & 0.990626 & 0.988 \\
\hline Netherlands & 1.152466 & 1.273292 & 1.083762 & 1.167 \\
\hline Poland & 0.96365 & 0.856115 & 0.98357 & 0.933 \\
\hline Portugal & 0.985389 & 0.925334 & 0.952525 & 0.954 \\
\hline Romania & 0.900178 & 0.76182 & 0.980748 & 0.876 \\
\hline Slovak Republic & 0.933982 & 0.871451 & 0.963814 & 0.961 \\
\hline Slovenia & 0.981938 & 0.937768 & 0.963814 & 1.165 \\
\hline Sweden & 1.13645 & 1.319093 & 1.054128 & 0.788 \\
\hline Ukraine & 0.797182 & 0.775084 & 0.793065 & \\
\hline & & & & \\
\hline
\end{tabular}

As it can be seen from Table 9 and Fig. 1, Germany, Denmark, Finland, Ireland, Luxembourg, Netherlands, Sweden have the highest economic development among the EU countries. The countries that have certain economic difficulties are: Bulgaria, Greece, Croatia and Ukraine.

Social component of sustainable development is the resulting country score of The Social Progress Index (SPI), Human Development Index (HDI) and Quality of Life Index (QLI), Table 10 and Fig. 2. This is the fourth stage of the calculation algorithm. Previously, the average values of the indicator for each of the ratings were found and the score of each country in the rating was standardised by dividing the rating score by the average value. 
Table 10. Social component of sustainable development of EU countries and Ukraine. Source: own calculations based on SPI 2020; HDI 2020; QLI 2021

\begin{tabular}{|c|c|c|c|c|}
\hline Country & SPI & $\mathrm{HDI}$ & QLI & $\begin{array}{l}\text { Social component of } \\
\text { sustainable development }\end{array}$ \\
\hline Austria & 1.036788 & 1.032888 & 1.174146 & 1.079 \\
\hline Belgium & 1.036325 & 1.04297 & 0.971469 & 1.016 \\
\hline Bulgaria & 0.925116 & 0.914139 & 0.81341 & 0.883 \\
\hline Cyprus & 1.003657 & 0.993678 & 0.927496 & 0.974 \\
\hline Czech Republic & 1.004237 & 1.008242 & 1.006493 & 1.006 \\
\hline Germany & 1.049067 & 1.060895 & 1.138027 & 1.082 \\
\hline Greece & 0.993695 & 0.994799 & 0.836073 & 0.938 \\
\hline Denmark & 1.06934 & 1.053053 & 1.223334 & 1.113 \\
\hline Spain & 1.027637 & 1.012723 & 1.058965 & 1.033 \\
\hline Estonia & 1.01084 & 0.99928 & 1.117425 & 1.041 \\
\hline Finland & 1.064474 & 1.050812 & 1.17685 & 1.096 \\
\hline France & 1.028448 & 1.009362 & 0.970439 & 1.002 \\
\hline Croatia & 0.94898 & 0.953349 & 1.005013 & 0.969 \\
\hline Hungary & 0.938554 & 0.95671 & 0.862791 & 0.918 \\
\hline Ireland & 1.046635 & 1.069857 & 0.971469 & 1.028 \\
\hline Italy & 1.011998 & 0.99928 & 0.892536 & 0.966 \\
\hline Lithuania & 0.972727 & 0.988077 & 1.030251 & 0.997 \\
\hline Luxembourg & 1.037483 & 1.026166 & 1.180198 & 1.079 \\
\hline Latvia & 0.963692 & 0.970153 & 0.950223 & 0.961 \\
\hline Malta & 0.983385 & 1.002641 & 0.927496 & 0.971 \\
\hline Netherlands & 1.05486 & 1.057534 & 1.180198 & 1.096 \\
\hline Poland & 0.976782 & 0.985837 & 0.854035 & 0.937 \\
\hline Portugal & 1.016979 & 0.967912 & 1.042419 & 1.009 \\
\hline Romania & 0.907624 & 0.927583 & 0.847983 & 0.894 \\
\hline Slovak Republic & 0.963228 & 0.963431 & 0.963679 & 0.963 \\
\hline Slovenia & 1.016052 & 1.027287 & 1.082916 & 1.042 \\
\hline Sweden & 1.061347 & 1.058654 & 1.103518 & 1.074 \\
\hline Ukraine & 0.85005 & 0.872689 & 0.691147 & 0.800 \\
\hline
\end{tabular}

Table 10 and Fig. 2 show, that Austria, Germany, Denmark, Finland, Luxembourg, Netherlands, Portugal, Sweden have the highest social development among the EU countries. These countries have shown a high level of social responsibility. Among the countries that have certain social problems can be distinguished: Bulgaria, Greece, Hungary, Romania, as well as Ukraine. In general, it should be noted that the social inequality of the studied countries is not significant. 


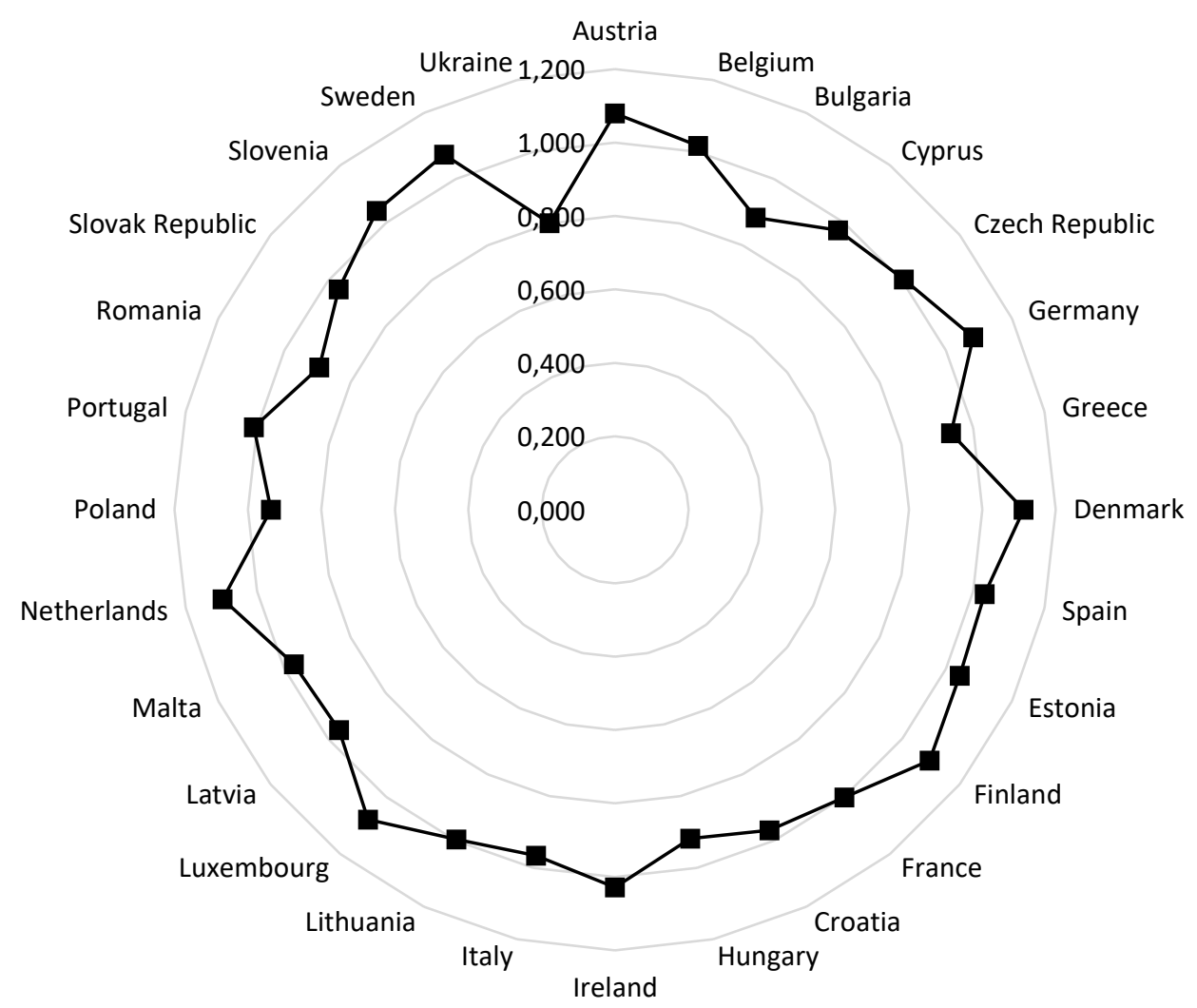

Fig. 2. Social component of sustainable development of EU countries and Ukraine Source: own calculations based on SPI 2020; HDI 2020; QLI 2021

The environmental component of sustainable development is the result of the country's environmental performance score, Table 11 and Fig. 3. This is the fifth stage of the calculation algorithm. Previously, the average value of the indicator was found and the score of each country in the ranking was standardized by dividing the rating score by the average value.

Table 11. Environmental component of sustainable development of EU countries and Ukraine. Source: own calculations based on EPI 2020

\begin{tabular}{|l|l|l|l|l|l|}
\hline No. & Economy & $\begin{array}{l}\text { Environmental } \\
\text { component } \\
\text { of sustainable } \\
\text { development }\end{array}$ & No. & Economy & $\begin{array}{l}\text { Environmental component } \\
\text { of sustainable development }\end{array}$ \\
\hline 1 & Austria & 1.138595 & 15 & Ireland & 1.041328 \\
\hline 2 & Belgium & 1.04848 & 16 & Italy & 1.015581 \\
\hline 3 & Bulgaria & 0.815326 & 17 & Lithuania & 0.899719 \\
\hline 4 & Cyprus & 0.926897 & 18 & Luxembourg & 1.177216 \\
\hline 5 & Czech Republic & 1.015581 & 19 & Latvia & 0.881124 \\
\hline 6 & Germany & 1.104266 & 20 & Malta & 1.01129 \\
\hline 7 & Greece & 0.988404 & 21 & Netherlands & 1.077088 \\
\hline 8 & Denmark & 1.180077 & 22 & Poland & 0.871111 \\
\hline 9 & Spain & 1.062784 & 23 & Portugal & 0.958365 \\
\hline 10 & Estonia & 0.934049 & 24 & Romania & 0.925466 \\
\hline 11 & Finland & 1.128582 & 25 & Slovak Republic & 0.97696 \\
\hline 12 & France & 1.144317 & 26 & Slovenia & 1.029885 \\
\hline 13 & Croatia & 0.90258 & 27 & Sweden & 1.125722 \\
\hline 14 & Hungary & 0.911162 & 28 & Ukraine & 0.708046 \\
\hline
\end{tabular}




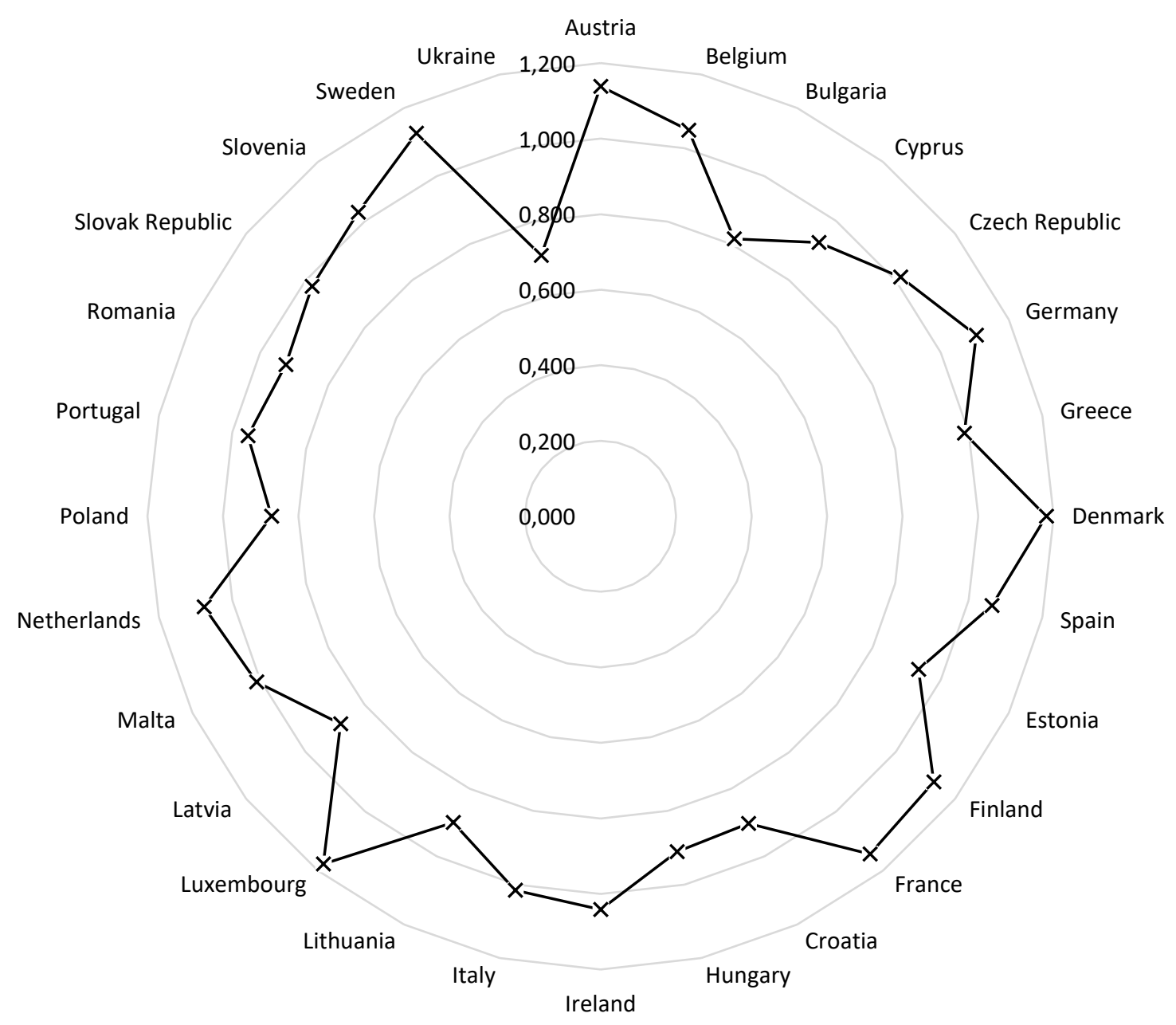

Fig. 3. Environmental component of sustainable development of EU countries and Ukraine Source: own calculations based on SPI 2020; HDI 2020; QLI 2021

As can be seen from Table 11 and Fig. 3, Austria, Belgium, Germany, Denmark, Finland, France, Luxembourg, Netherlands, Sweden have the highest environmental sustainability. Among the countries that have a certain ecological instability we can note Bulgaria, Estonia, Greece, Croatia, Hungary, Lithuania, Latvia, Poland, and Ukraine.

Sustainable Development Index is calculated according to the methodology mentioned above, Table 12, Fig. 4 and 5. This is the sixth stage of calculating the index of sustainable development of the world using the index method and methodology for calculating the integrated index of human development, adapted to the indicators of sustainable development. 
Table 12. Components of the Sustainable Development Index of the EU countries and Ukraine. Source: Author's

\begin{tabular}{|c|c|c|c|c|}
\hline Country & Economic component & Social component & Environmental component & $\begin{array}{c}\text { Sustainable } \\
\text { Development Index }\end{array}$ \\
\hline Austria & 1.056635 & 1.079332 & 1.138595 & 1.090979 \\
\hline Belgium & 1.031985 & 1.016402 & 1.04848 & 1.032206 \\
\hline Bulgaria & 0.910206 & 0.882753 & 0.815326 & 0.868501 \\
\hline Cyprus & 0.97864 & 0.974349 & 0.926897 & 0.959672 \\
\hline Czech Republic & 1.018744 & 1.006323 & 1.015581 & 1.013536 \\
\hline Germany & 1.121771 & 1.081956 & 1.104266 & 1.102544 \\
\hline Greece & 0.846447 & 0.938449 & 0.988404 & 0.922532 \\
\hline Denmark & 1.147187 & 1.11268 & 1.180077 & 1.146318 \\
\hline Spain & 1.009894 & 1.032929 & 1.062784 & 1.034976 \\
\hline Estonia & 1.042636 & 1.041188 & 0.934049 & 1.00464 \\
\hline Finland & 1.143332 & 1.095958 & 1.128582 & 1.122449 \\
\hline France & 1.047384 & 1.002457 & 1.144317 & 1.063096 \\
\hline Croatia & 0.847831 & 0.968784 & 0.90258 & 0.905053 \\
\hline Hungary & 0.926853 & 0.918435 & 0.911162 & 0.918794 \\
\hline Ireland & 1.119535 & 1.02845 & 1.041328 & 1.062355 \\
\hline Italy & 0.957999 & 0.966416 & 1.015581 & 0.979673 \\
\hline Lithuania & 0.962422 & 0.996724 & 0.899719 & 0.9521 \\
\hline Luxembourg & 1.085896 & 1.079074 & 1.177216 & 1.113179 \\
\hline Latvia & 0.94963 & 0.96132 & 0.881124 & 0.930007 \\
\hline Malta & 0.988095 & 0.970645 & 1.01129 & 0.98987 \\
\hline Netherlands & 1.167249 & 1.09601 & 1.077088 & 1.112781 \\
\hline Poland & 0.932722 & 0.936899 & 0.871111 & 0.913074 \\
\hline Portugal & 0.954101 & 1.008626 & 0.958365 & 0.973386 \\
\hline Romania & 0.876152 & 0.893749 & 0.925466 & 0.898225 \\
\hline Slovak Republic & 0.92227 & 0.963446 & 0.97696 & 0.95394 \\
\hline Slovenia & 0.961002 & 1.041679 & 1.029885 & 1.010219 \\
\hline Sweden & 1.164769 & 1.074312 & 1.125722 & 1.120986 \\
\hline Ukraine & 0.788385 & 0.800372 & 0.708046 & 0.764476 \\
\hline
\end{tabular}




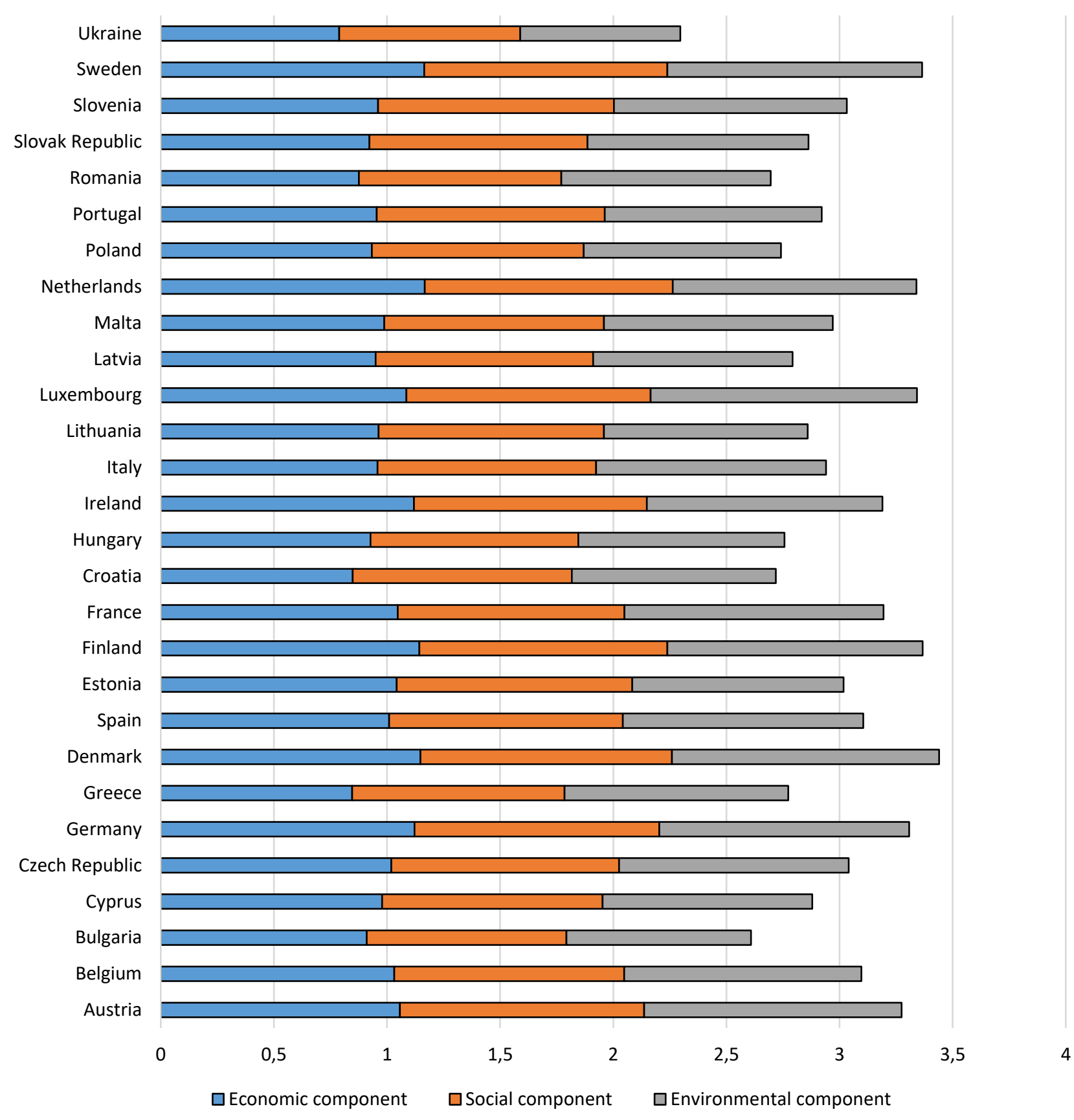

Fig. 4. Components of the Sustainable Development Index of the EU countries and Ukraine on the basis of equation (3). Source: Author's 


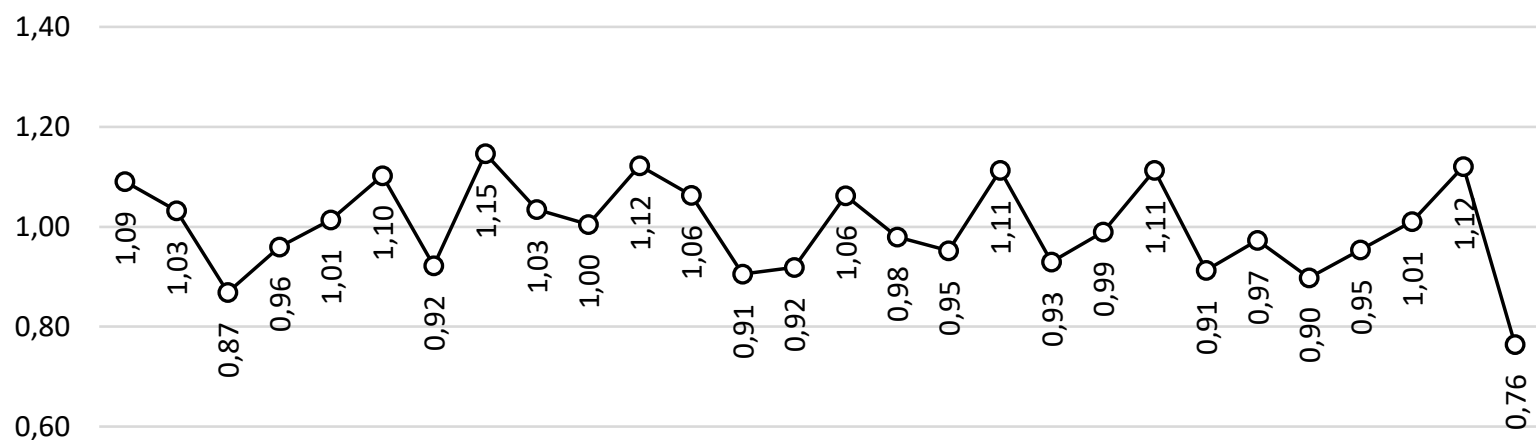

0,40

0,20

0,00

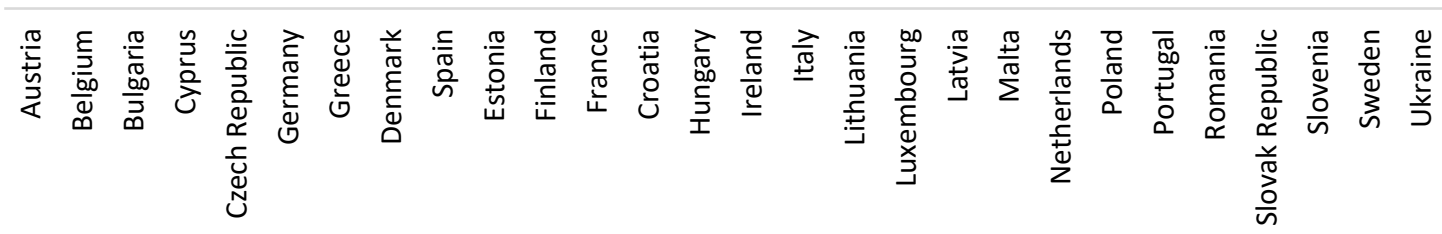

Fig. 5. Sustainable Development Index of the EU countries and Ukraine on the basis of equation (3) Source: Author's

The average level of sustainable development in the EU countries is 0.998556 points. Therefore, Estonia, Slovenia, Czech Republic, Belgium, Spain, Ireland, France, Austria, Germany, Netherlands, Luxembourg, Sweden, Finland, Denmark have a high level of sustainable development. Greece, Latvia, Lithuania, Slovak Republic, Cyprus, Portugal, Italy, Malta have an average level of sustainable development. Hungary, Poland, Croatia, Romania, Bulgaria and Ukraine have an insufficient level of sustainable development.

To confirm the objectivity of the proposed calculation, a comparison was made between the data obtained by the authors and the data for the studied countries in the Sustainable Development Report (2021). The correlation coefficient, Sustainable Development Index, calculated by the authors, and the index, which consists of 17 groups of indicators and contains more than 100 criteria, is 0.66 . This indicates a moderately high level of correlation, so it can be argued that the calculation proposed by the authors can be used in various studies of sustainable development.

\section{Conclusions}

1. The author's vision of the sustainable development index - multidimensional Sustainable Development Index is proposed and tested on the example of the EU countries and Ukraine, using the index method and the methodology for calculating the integral human development index, adapted to the indicators of sustainable development.

2. It has been substantiated the use of international ratings of Global Competitiveness Index, Global Innovation Index and Index of Economic Freedom as an economic component of the Sustainable Development Index. They allow assessing the state of the economy in terms of the level of innovation, international trade, institutional prerequisites, business environment, education system, etc.

3. Basing on the results of the calculation of the economic component, it was determined that Germany, Denmark, Finland, Ireland, Luxembourg, the Netherlands and Sweden have the highest economic development among the EU countries. The countries that have certain economic difficulties are: Bulgaria, Greece, Croatia and Ukraine.

4. In order to analyse the social component of the Sustainable Development Index, the use of the international ratings of Social Progress Index, Human Development Index and Quality of Life Index was determined. They allow assessing the social development of the country in terms of basic needs, basics of well-being, development opportunities, average life expectancy, educational level, etc.

5. Basing on the results of the calculations, it was determined that the highest social development among the EU countries have Austria, Germany, Denmark, Finland, Luxembourg, the Netherlands, Portugal, Sweden. These countries have shown a high level of social responsibility. Among the countries that have certain social problems can be distinguished: Bulgaria, Greece, Hungary, Romania, Ukraine. 
6. It is proposed to consider the environmental measuring of sustainable development using the Environmental Performance Index. It records the country's achievements on its way to sustainable environmental development through the level of infant mortality, chemical pollution and dustiness of the atmosphere, the provision of drinking water and its sufficient purification, the state of ozone, the content of nitrates in water consumption, water consumption, share of natural and protected areas, level of deforestation, agriculture support level, depletion of fish stocks, share of alternative energy fill sources, energy efficiency and $\mathrm{CO}_{2}$ emissions.

7. It is emphasised that Austria, Belgium, Germany, Denmark, Finland, France, Luxembourg, the Netherlands, Sweden have the highest environmental sustainability. Among the countries that have a certain ecological instability we can note Bulgaria, Estonia, Greece, Croatia, Hungary, Lithuania, Latvia, Poland, Ukraine.

8. Based on the results of the Sustainable Development Index calculation, it was concluded that Estonia, Slovenia, Czech Republic, Belgium, Spain, Ireland, France, Austria, Germany, Netherlands, Luxembourg, Sweden, Finland, Denmark have a high level of sustainable development; Greece, Latvia, Lithuania, Slovak Republic, Cyprus, Portugal, Italy, Malta have an average level of sustainable development; Hungary, Poland, Croatia, Romania, Bulgaria and Ukraine have an insufficient level of sustainable development.

\section{Impact}

To ensure sustainable development, the following initial conditions can be identified: economic development, which is supported on the basis of a modified market system; natural and ecological sustainability; close international cooperation to achieve the goals of sustainable development; sustainable social development based on the principle of justice (table 13).

Table 13. SWOT-analysis of the proposed calculation of the Sustainable Development Index. Source: Author's

\begin{tabular}{|c|c|}
\hline Strengths & Weaknesses \\
\hline $\begin{array}{l}\text { - simplicity and clarity of the proposed index } \\
\text { - basing the calculation methodology for the well-known and } \\
\text { proven global assessment methods } \\
\text { - the possibility of comparison of rankings, developed on the basis of the } \\
\text { author's methodology with the other, complementary rankings, } \\
\text { prepared on the basis of traditional methodology; } \\
\text { - the opportunity of assessing not only the level of sustainable } \\
\text { development of any country, but also its economic, social and } \\
\text { environmental components separately; } \\
\text { - comprehensiveness important for various groups: administrative and } \\
\text { statistical services at the level of countries, regions and international } \\
\text { organizations and the academic community of social sciences as well; } \\
\text { - opportunities to easily replace any component (rating) with another, } \\
\text { make a calculation for other countries or add more if the study requires. }\end{array}$ & $\begin{array}{l}\text { - dependence on world rankings and } \\
\text { their imperfect and incomplete } \\
\text { evaluation methods } \\
\text { - duplicating errors resulting from } \\
\text { traditional world rankings of the SDI; } \\
\text { - delay in presenting rankings, based } \\
\text { on the new SDI. }\end{array}$ \\
\hline Opportunities & Threats \\
\hline $\begin{array}{l}\text { - the requirement for multidimensional assessment by administrative and } \\
\text { statistical services at the level of countries, regions, international } \\
\text { organizations and the academic community of social sciences; } \\
\text { - the need to use of the most simple and easy understandable indicators } \\
\text { of the sustainable development, which take into account as many } \\
\text { aspects of economic, social and environmental life as possible; } \\
\text { - the necessity to boost sustainable development in countries and regions } \\
\text { around the world; } \\
\text { - the opportunity to identify leaders of the sustainable development with } \\
\text { the use of an objective measurement/ evaluation tool. }\end{array}$ & $\begin{array}{l}\text { - } \text { originality } \\
\text { unwillingness to replace the already } \\
\text { Index the Sustainable Development } \\
\text { comprehensive one; } \\
\text { - the need to revalue the existing } \\
\text { world rankings with the new SDI; } \\
\text { - the originality of the new method, } \\
\text { developed by the academic } \\
\text { community, not in statistics services; } \\
\text { - the challenge of the introducing the } \\
\text { new method of calculating SDI into } \\
\text { the practice of the sustainable } \\
\text { development evaluators. }\end{array}$ \\
\hline
\end{tabular}


Thus, the calculation of the Sustainable Development Index and its components proposed by the authors on the example of the EU and Ukraine is based on objective international rankings that have a transparent calculation methodology, constant updating and cover most countries. The proposed calculation option has a clear algorithm that can be easily adapted to other countries, or the expansion of components. These aspects make it possible to identify the countries with the best level of economic, social and environmental development; calculate the index of sustainable development of any country in the world.

\section{Conflict of interest}

There are no conflicts to declare.

\section{Acknowledgements}

This research was part of the research theme "The specifics of Ukraine's European economic integration in terms of association with the EU and the development of the fourth industrial revolution" from V.N. Karazin Kharkiv National University and within the framework of the European educational project Jean Monnet Module "European integration of Ukraine in the conditions of Industry 4.0" (611674-EPP-1-2019-1-UA-EPPJMO-MODULE) for 2019-2022 with the participation of V.N. Karazin Kharkiv National University.

\section{References}

[1] G.H. Brundtland, The Elders - Gro Harlem Brundtland, (2021). https://theelders.org/profile/gro-harlembrundtland.

[2] H.E. Daly, Towards a Steady State Economy, W.H. Freeman, San Francisco, 1973.

[3] G. Clark, Evolution of the global sustainable consumption and production policy and the United Nations Environment Programme's (UNEP) supporting activities, J. Clean. Prod. 15 (2007) 492-498. https://doi.org/10.1016/j.jclepro.2006.05.017.

[4] D.H. Meadows, D.L. Meadows, J. Randers, W.W. Behrens, The Limits to Growth: A report for the Club of Rome's Project on the Predicament of Mankind, Universe Books, 1972. https://doi.org/10.1349/ddlp.1.

[5] J.H. Hulse, Sustainable Development at Risk: Ignoring the Past, Cambridge University Press India Pvt. Ltd. and International Development Research Centre, Ottawa, 2007.

[6] A. Onishi, Futures of global interdependence (FUGI) global modeling system, J. Policy Model. 27 (2005) 101135. https://doi.org/10.1016/j.jpolmod.2004.10.002.

[7] D. BUGAYKO, Y. KHARAZISHVILI, V. LIASHENKO, A. KWILINSKI, Systemic approach to determining the safety of sustainable development of air transfport: indicators, level, threates, J. Eur. Econ. 20 (2021) 146-182. https://doi.org/10.35774/jee2021.01.146.

[8] N. Dalevska, V. Khobta, A. Kwilinski, S. Kravchenko, A model for estimating social and economic indicators of sustainable development, Entrep. Sustain. Issues. 6 (2019) 1839-1860. https://doi.org/10.9770/jesi.2019.6.4(21).

[9] T. Pimonenko, Y. Us, L. Lyulyova, N. Kotenko, The impact of the macroeconomic stability on the energyefficiency of the European countries: A bibliometric analysis, in: J. Abouchabaka, S. Bourekkadi, O. Omari, K. Slimani (Eds.), E3S Web Conf., 2021: p. 00013. https://doi.org/10.1051/e3sconf/202123400013.

[10] L. Starchenko, S. Lyeonov, T. Vasylieva, T. Pimonenko, O. Lyulyov, Environmental management and green brand for sustainable entrepreneurship, in: J. Abouchabaka, S. Bourekkadi, O. Omari, K. Slimani (Eds.), E3S Web Conf., 2021: p. 00015. https://doi.org/10.1051/e3sconf/202123400015.

[11] T. Khudyakova, E. Lyaskovskaya, Improving the sustainability of regional development in the context of waste management, Sustain. 13 (2021) 1-21. https://doi.org/10.3390/su13041755.

[12] M. Tvaronavičienè, Effects of climate change on environmental sustainability, in: W. Strielkowski (Ed.), E3S Web Conf., 2021: p. 01005. https://doi.org/10.1051/e3sconf/202125001005.

[13] N. Letunovska, O. Lyuolyov, T. Pimonenko, V. Aleksandrov, Environmental management and social marketing: A bibliometric analysis, in: J. Abouchabaka, S. Bourekkadi, O. Omari, K. Slimani (Eds.), E3S Web Conf., 2021: p. 00008. https://doi.org/10.1051/e3sconf/202123400008.

[14] Innovation, Social and Economic Challenges, in: Proc. Int. Sci. Online Conf., Sumy State University, Sumy, 2020.

[15] L.H. Melnyk, Osnovy stiikoho rozvytku: posibnyk dlia pisliadyplomnoi osvity, Universytetska knyha, Sumy, 1990.

[16] M. Zghurovskyi, Dzerkalo tyzhnia, 19 (2006).

[17] O. V. Khanova, Stalii rozvitok krain UE: metodika i indykatori ociniuvannia, Probl. Ekon. 3 (2017) $20-32$.

[18] M.A. Ganaie, F. Zafar, S. Tahir, S. Pittafi, Impact of COVID-19 on SMEs: SMEDA - ADBI - APO Joint Survey Report (Pakistan and Regional Countries including; Bangladesh, India, Indonesia, Malaysia, Mongolia, Lao PDR and 
Vietnam), 2021. https://doi.org/10.13140/RG.2.2.11602.48329.

[19] Y. Us, T. Pimonenko, T. Tambovceva, J.-P. Segers, Green Transformations In The Healthcare System: The Covid19 Impact, Heal. Econ. Manag. Rev. 1 (2020) 48-59. https://doi.org/10.21272/hem.2020.1-04.

[20] OECD, The Economic Significance of Natural Resources: Key points for reformers in Eastern Europe, Caucasus and Central Asia, 2011.

[21] E. Kochańska, Selected problems of water, electricity and waste management in Brazil in the context of its impact on climate change mitigation, Acta Innov. 32 (2019) 29-39.

https://doi.org/10.32933/actainnovations.32.4.

[22] J. Bojarska, P. Złoty, W.M. Wolf, Life cycle assessment as tool for realization of sustainable development goalstowards sustainable future of the world: Mini review, Acta Innov. 38 (2021) 49-61. https://doi.org/10.32933/Actalnnovations.38.5.

[23] M. Tabatabaei, M. Aghbashlo, The critical role of advanced sustainability assessment tools in enhancing the real-world application of biofuels, Acta Innov. 37 (2020) 67-73.

https://doi.org/10.32933/actainnovations.37.6.

[24] Global Competitiveness Report (2019), 2019. https://www.weforum.org/reports/how-to-end-a-decade-oflost-productivity-growth.

[25] Global Innovation Index Report, 2019. https://www.wipo.int/publications/en/series/index.jsp?id=129.

[26] Index of Economic Freedom, (2021). https://www.heritage.org/index/.

[27] The Social Progress Index, (2020). https://legacy.socialprogress.org/.

[28] The 2020 Human Development Report, New York, USA, 2020. http://hdr.undp.org/en/2020-report.

[29] Quality of Life Index, (2020). https://www.numbeo.com/quality-of-life/rankings_by_country.jsp?title=2020.

[30] C.J. Barr, J.A. Mertens, C.A. Schall, Critical cellulase and hemicellulase activities for hydrolysis of ionic liquid pretreated biomass, Bioresour. Technol. 104 (2012) 480-485. https://doi.org/10.1016/j.biortech.2011.10.101. 